\title{
REPORT ON THE XXXV ASTIN COLLOQUIUM \\ JUNE 6-9 2004, BERGEN, NORWAY
}

\section{Introduction}

The 35th International ASTIN Colloquium was held in Bergen, Norway from June 6 to 9,2004. There were 190 participants with 46 accompanying persons from 27 countries. The scientific program, in the typical format of actuarial conferences, consisted of organized and contributed sessions. All that went on can be downloaded from the colloquium website (astin2004.no) up to January 2006.

Bergen is a hilly fjord town on the Norwegian coast, founded in the Middle Ages. The social program was a reflection of these facts with the opening reception held at a scenic hill top restaurant, the closing dinner in a medieval hall that was built almost 800 years ago and with the main excursion taking participants inside some of the fjords of Western Norway with waterfalls and flush, green hills.

\section{Organized sessions}

Opening and closing key note addresses were delivered by

- Dr Stefan Lippe, Head of Casualty and Property, Swiss Re, Switzerland

- Professor Jean Lemaire, Wharton School of Business, USA

Dr. Lippe who spoke on "Mathematics in the re-insurance industry" reviewed the role of mathematics and computer simulations, arguing for transparency and structured approaches to problems that are very complex indeed. Professor Lemaire took the audience through an extremely witty hour on "Challenges to Actuarial Science in the $21^{\text {th }}$ Century" emphasizing creativity and communication skills as crucial for the actuarial profession in the decades ahead of us.

Three thematic sessions addressed themes of central importance for the insurance industry. All of them were run with three or four speakers who were partly actuaries and partly people from outside the profession. The guiding idea was that the problems under discussion are much broader than actuarial method in a narrow sense and need input from other scientific areas for their modelling and solutions. Themes and speakers were:

- Climatic Change and Insurance

Speakers: Hans von Storch, David Anderson, Gerhard Berz.

- The World of Insurance Fraud with Actuarial Perspective Speakers: Tommy Short, Montserrat Guillen, Irene Lægreid, Richard Derrig

- Genetics and Insurance

Speakers: Tim Bishop, William Nolan, Piet De Jong 
Details about the speakers, their titles and talks are available on the conference web site.

\section{Working sessions}

The conference received 22 written contributions. All can be downloaded from the website. Their presentations during the conference were divided into eight working sessions which were run in the afternoons in parallels of two. Speaking time varied between 20 and 30 minutes for each talk. The list of the contributed papers (alphabetical order) is as follows:

AASE, K.K. Area yield futures and future options: Risk management and hedging.

Ahlgrim, K.C., D'Arcy, S.P. and GorvetT, R.W. Asset-liability modeling for insurers: Incorporating a regime-switching process for equity retuns into a Dynamic Financial Analysis model.

BRAUN, C. The prediction error of the chain ladder method applied to correlated run-off triangles.

CHRistofides, S. Pricing of catastrophe linked securities.

FLORES, C. Multiplicative cascade models for rain in hydro-meteorological disasters risk management.

CAIRns, A.J.G. and Rosas, S.A.G. A family of term-structure models with stochastic volatility for use in dynamic financial analysis.

CONGER, R.F., HuRley, J.D. and Lowe, S.P. How might the presentation of liabilities at fair value have affected the reported results of US property and casualty insurers?

Cummins, J.D., Miltersen, K.R., and Persson, S.-A. International comparison of interest rate guarantees in life insurance.

D'ARCY, S.P. and DERrIG, R.A. The economics of insurance fraud investigation: Evidence of a Nash Equilibrium.

De Lourdes Centeno, M. and e Silva, J.A. Applying the proportional hazard premium calculation principle.

DOS REIS, A.D.E. The compound binomial model revisited.

GARCIA, J.M.A. Explicit solutions for survival probabilities in the classical risk model.

Goovaerts, M.J., van DEN Borre, E. and LAevin, R.J.A. Managing economic and virtual economic capital within financial conglomerates.

Holtan, J. Pragmatic insurance option pricing.

LANDSMAN, Z. and VALDEZ, E.A. Tail conditional expectations for exponential dispersion models.

LESCOURRET, L. and RoBerT, C. Estimating the probability of two dependent catastrophic events.

Neunaus, W. On the estimation of outstanding claims.

OHLSSON, E. Credibility rating in a multiplicative tariff.

Rempala, G.A. and DerRIG, R.A. Modelling hidden exposures in claim severity via the EM algorithm.

Roustant, O., Laurent, J.-P., Bay, X. and Carrato, L. A bootstrap approach to price uncertainty of weather derivatives.

RYDTGAARD, M. and SAVELLI, N. Risk-based capital requirements for property and liability insurers according to different reinsurance strategies and the effect of profitability.

Wu, X. and YueN, Y. On an interaction risk model with delayed claims.

WÜTRICH, M.V. Aggregation and diversification effect of dependent random variables.

Oslo, Norway, September 2004

Erik Bølviken 